\title{
二成層密度流における多重フロント現象の観測と それに基づく連行量算定法
}

\section{1. 緒言}

原子力・火力発電所の温排水拈よび河口部海域に打け る河川水等の拡散現象は, 昨今に打ける産業活動の大規 模化に伴って重要な社会的関心事となり，その影響範囲 の規定に関しては, 内外において数多くの研究成果が報 告されている。しかしながら，これら従来の研究におい ては, 放水口から水域表面に放流された排水の水温もし くは濁りは, 沖合方向に連続関数的に低減していくもの として取り扱われてきている. しかし，水温や濁りの低 減現象は, 主として排水と放流水域流体との間に形成さ れる内部境界面の不安定化に起因することを考虑する

と, 本来, 不連続な現象であるはずであ る. 事実, 実際に発電所放水口や河口部の 水域に怙ける放流水の挙動を調べてみる と，放流された表層水の密度が沖合方向に 段階的に低減していくことを示唆する結果 が得られている。このような事例として, 本論では, 1979 年 10 月 8 日に富士川と酒 勾川の河口部に打いて航空写真観測安行っ て得られた結果を提示する。 また，温排水 の例として, Scarpace らによるポイント ビーチ発電所での熱映像観測の結果を示 す.これらの実測例においてはいずれも， 密度差の不連続な变化に起因すると考えら れる多重フロント (front-laden) 現象の存在 が認められる. 本論では, この多重フロン トは内部境界面上の攪乱波に起因して発生 するものとする考え方に立って，㩭乱波の 不安定化条件を攪乱波波長 (多重フロント の間隔) の項でもって解析的に表現するこ とを試み,さらに，その結果を基にして， 放流水の拡散範囲算定上に扔いて重要なパラメータであ る, 下層水の表層流への連行量を求める近似式を提示す る.

* 正会員 工博 東京理科大学教授 理工学部土木工学科

** 正会員 工博りモートセンシング技術センター
大西 外 明*. 田中総太郎**

\section{2. 伊豆・東海沖における 河川濁水分布の観測 例}

1979 年 10 月中旬, 東海地方一帯は豪雨に見舞れたが, 降雨があがった翌日の 10 月 22 日にたまたま人工衛星 Landsat が日本沿岸水域一帯の観測データを送信してき ている，そのデータを基にして，日本列島各地沿岸水域 の流動特性を検討しつつあるが，流動特性は海底地形に より著しく影響されることが判明しており，そのため に, この種の研究に打いては, 海底地形と Landsat 映像 の中の流動のパターンとを合成した Landsat Map 手法 が有効であることを提案した2). 図一1 は 1979 年 10 月

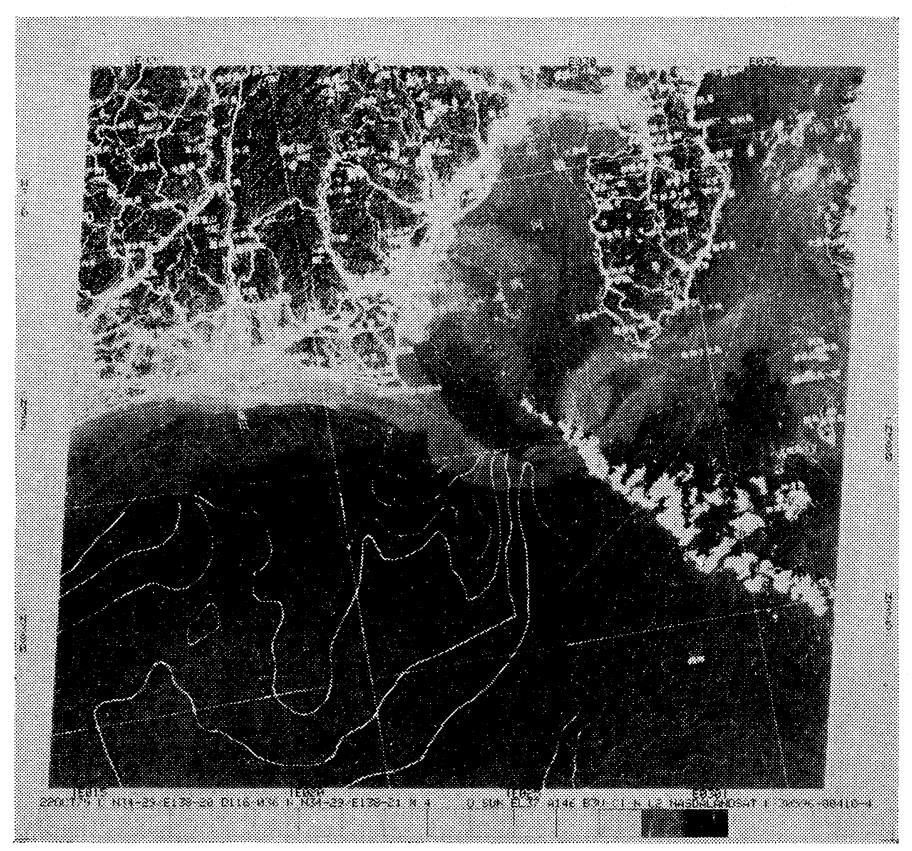

図一1 1979 年 10 月 29 日出水㭙の伊豆沖の Landsat map

29 日の Landsat バント 4 のデータを基に作った伊豆沖 の Landsat map である. 図一1において特に興味深いの は，天竜川およびそれより以東の陸側からの濁水が伊豆 半島先端部にまで達し，そこで伊豆海嶺の影響をうけて 大きな回転流を形成している点と, 帯状の濁水と海水と の間に形成されるフロントが急傾斜等深線と平行に走り 


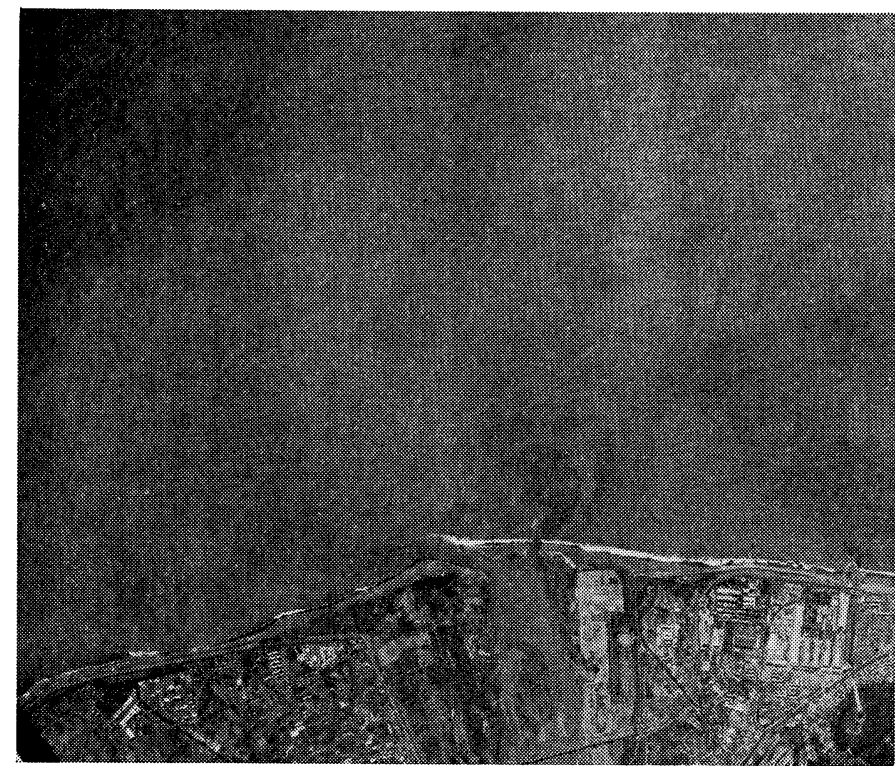

図一2 富士川河口の流況 (1978 年 10 月 8 日)

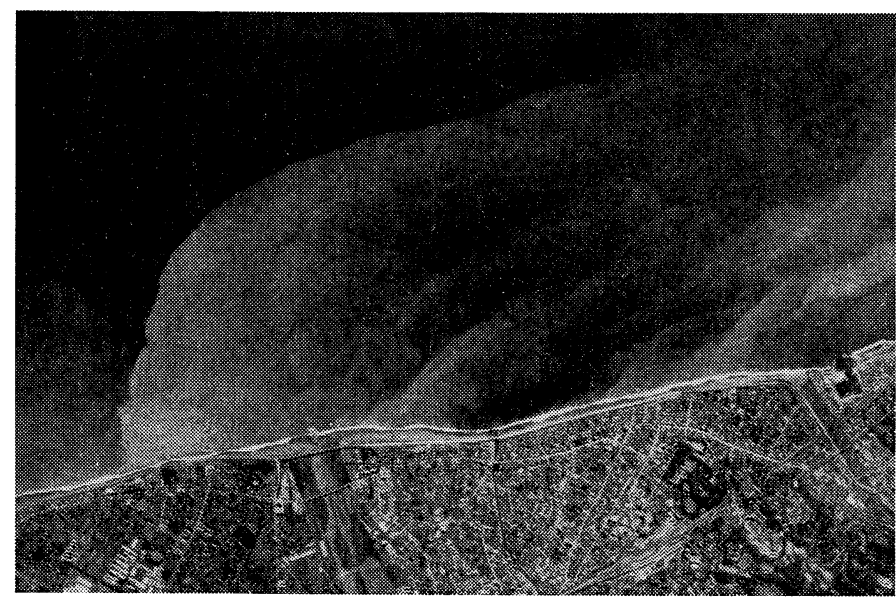

図一3 酒勾川河口の流況（1978 年 10 月 8 日）

つつ安定を保っている点である，後者は先に著者らが富 山湾内の流動特性に関連して報告した結果 ${ }^{3)}$ と一致す る。また前者は, 黑潮の蛇行現象をロスビー波の伝播と 停滞としてとらえた関根 $\left.{ }^{4}\right)$ の数值実験結果と符合するも のと考光られる．この水域に怙ける濁水分布と黑潮との 関係については機会を改めて報告することとし，本論文 では対象水域をせばめて河口部近傍の現象に注目する。 Landsat データは狭い水域における水理現象の詳細を検 討するのには適しえない面があり，この場合には通常の 航空写真は時には有用な情報をもたらす. 図一2 と図一 3 は, 1978 年 10 月 8 日の富士川と酒勾川の河口部の 観測結果である. 前日には流域一带に大降雨があったた め, 河川水は濁りをおびており, その濁水により海域に おいて形成される等濁り線は河口部を中心として，ほぼ 半円状に分布しているのが認められる. 特に富士川にお
いては，砂州先端から沿岸沿いに流出する 河川水と，砂州の裂目から沖合方向に流出 する河川水がそれぞれ半円状の不連続面を 形成しているのが興味をひく。

つぎに，図一2 および 図一3 に認められ るような濁り不連続面が発生する機構につ き考えて夕よう，密度 $\rho+\Delta \rho$ の水域の表層 に密度 $\rho$ の流体を放流する場合を想定す る.放流口の近傍領域では, 上層流の運動 量に起因した上下流体の混合が進み，上下 流体間の密度差は急速に隇少する，さら に, この領域より沖合の遠方領域では，淡 水/塩水 2 層流の場合には, 内部境界面の 不安定化に伴って混合が進み, 密度差は沖 合方向に漸隇するが，その内部境界面の不 安定化は後述の様に, 界面上の㩇乱波の一 波長に相当する位置ごとに発生するものと 考光られる。言いか党れば，上下流体間の 密度差 $\Delta \rho$ の変化は不連続な性状を有して いると考元られる。温水/冷水 2 層流に打 いては, さらに水面での熱収支が密度差の 変化槣与するが，その沖合方向の変化が 不連続であることには変りはない，図一2, 3 に示した観測結果と類似の現象は, 原子 力・火力発電所の温排水の場合にもみるこ とができる，例えば, Scarpace (1974) ら は, 1972 年以来週 2 回の頻度で, ミシガ ン湖畔のポイントビーチ原子力発電所（出 力 50 万 $\mathrm{kw} \times 2$ 基）の温排水の分布を熱赤 外線スキャナーにより調查を続けた結果, 多様な温排水分布パターンが観測された が，全体の $90 \%$ を占める 3 つの主要パ夕

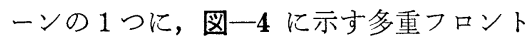
(front-laden) の分布パターンが含まれていると報告して いる ${ }^{5)}$. 同様のパターンはェッジウォータ発電所におい ても頻繁に発生している．この多重フロント型分布の特 徵は, 水温感知器により捉えられる水面映像の浱淡（水 温差）が, 沖合方向に不連続に变化し, 従来の温排水解 析における連続的変化の仮定と様相を異にしている点に

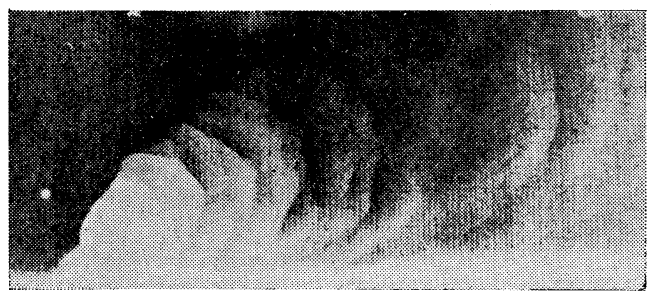

図一4 温排水における多重フロント現象 (ポイントビーチ発電所の例1) 
ある. Scarpace らは，この分布パターンの発生原因を発 電所運転状況の変動や放流水域の環境の変動によるもの としているが，同様の分布が河口部近傍海域における河 川水の場合に扔いても観測されることから， Scarpace ら の推論は当を得たものではなく，図一2, 3 および 図一4 に認められる多重フロント型の表層流分布は, 上・下両 層流体間の混合の周期的特性を示唆しているものと考元 られる.このことを，次節に拈いて解析的に示そう.

\section{3. 多重フロント型分布の発生に関する解析的 考察}

図一5 の様に一つの界面を介して隣り合う密度と速度 を異にする二層密度流を考光, 鉛直上向きに $y$ 軸, 界面 ぞいの流れ方向に $x$ 軸をとる.内部境界面を図一6の
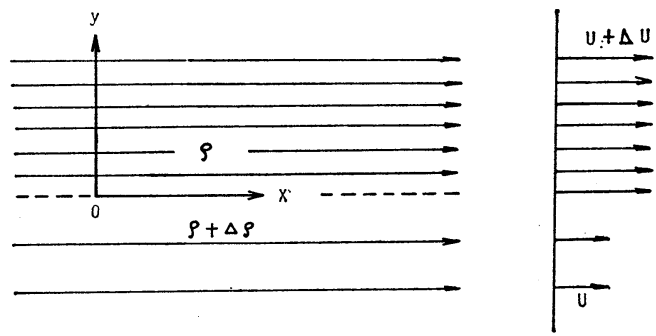

図一5 不連続な速度分布をもつ流れ

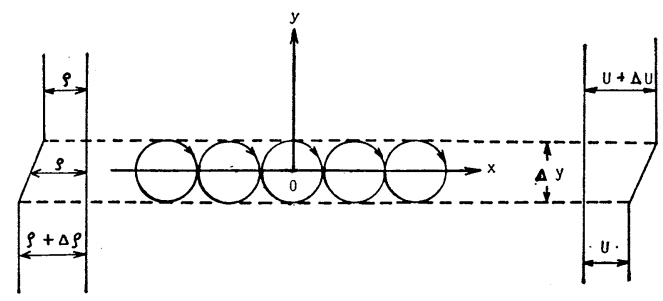

图一6 内部境界面を構成する洞度

様に厚さ $\Delta y$ の渦層と仮定し，その内での密度は図に示 す様に直線的に变化するものとする。一般に流速の $x$ 方 向および $y$ 方向の成分をそれぞれ $u$ および $v$ とする そ, 単位質量の流体が持つ $x y$ 平面に垂直な軸のまわり の渦度 $\zeta$ は

$$
\zeta=\frac{\partial v}{\partial x}-\frac{\partial u}{\partial y}
$$

で表わされ，その時間的変化は非粘性流体の場合には次 式で与光られる。

$$
\begin{aligned}
& \frac{D \zeta}{D t}=\frac{1}{\rho} \frac{\partial \rho}{\partial y} \cdot \frac{D u}{D t}-\frac{1}{\rho} \frac{\partial \rho}{\partial x} \frac{D v}{D t}+\frac{1}{\rho} \frac{\partial \rho}{\partial y} \frac{\partial \Omega}{\partial x} \\
& -\frac{1}{\rho} \frac{\partial \rho}{\partial x} \frac{\partial \Omega}{\partial y}
\end{aligned}
$$

ここに, $D / D t=\partial / \partial t+u \partial / \partial x+v \partial / \partial y, \Omega=$ 物体力ポテン シャルである.式 (2) はまた次のベクトル式によって表 示できる.

$$
\left.\frac{D \zeta}{D t}=-\left(\frac{1}{\rho} \operatorname{grad} \rho\right) \times \underset{(\text { 物体力) }}{(\operatorname{grad} \Omega}+\frac{D v(u, v)}{D t}\right)
$$

上式は, 物体力と慣性力の合力の方向が密度最大こう 配線方向と同一直線上にある場合には, $D \zeta / D t=0$, すな わち渦度が一定に保たれることを意味する，あるいは換 言すると, 渦層一内部境界面——内で渦度が一定な場 合には, 物体力と慣性力の合力は等密度面と直交するこ とを表わしている.この状態では内部境界面は安定し， 上・下両流体の混合は生じない，いま，この安定な状態 にある内部境界面に, 次式で表わされる微小攪乱波を加 光る。

$\eta=H \cos k x$

そのとき，内部境界面内には，つぎの 2 つの原因による 渦度変化が生じる。

（i）図一7 にしめす様な過層变位により誘起される 渦度变化 $\left(\xi_{1}\right)$.

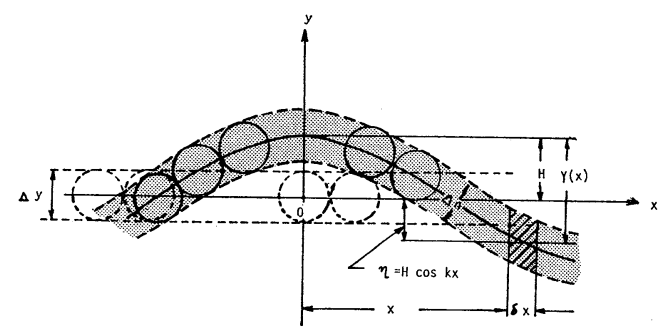

図一7攪乱による内部境界面（渦層）の変位

（ii）等密度面と（物体力）＋(慣性力）の合力の方向 とのずれに起因する式 (3) で表わされる渦度变化 $\left(\xi_{2}\right)$. 厚さ $\Delta y$ の内部境界面内の速度こう配を

$$
\alpha=\frac{\Delta U}{\Delta y}
$$

と表わすと， $\xi_{1}$ は次式で与えられる5).

$$
\xi_{1}=\frac{1}{2} \alpha^{2} \Delta y k^{2} H \sin k x
$$

また, 定常な 2 成層密度流の場合には, 式 (3) におい $\tau \operatorname{grad} \Omega=\boldsymbol{g}$ (=重力の加速度), $D \boldsymbol{v} / D t=0$ と置き

$$
\xi_{2}=-\left(\frac{1}{\rho} \operatorname{grad} \rho\right) \times g
$$

をうる。内部境界面が変位したのちも, 密度最大こう配 の方向は一般に内部境界面と直交する $n$ 方向をとると 考えてよいので，その方向の単位ベクトルを $\boldsymbol{n}$ とし，

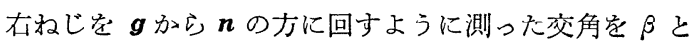
すると (図一8 参照), 変位が大きくない時には式 (7) は 次式となる。

$$
\begin{aligned}
\xi_{2} & =\boldsymbol{g} \times \boldsymbol{n}\left|\frac{1}{\rho} \frac{\Delta \rho}{\Delta n}\right| \\
& =|\boldsymbol{g}|\left|\frac{1}{\rho} \frac{\Delta \rho}{\partial n}\right| \sin \beta \simeq|\boldsymbol{g}|\left|\frac{1}{\rho} \frac{\Delta \rho}{\Delta y}\right| \sin \beta
\end{aligned}
$$




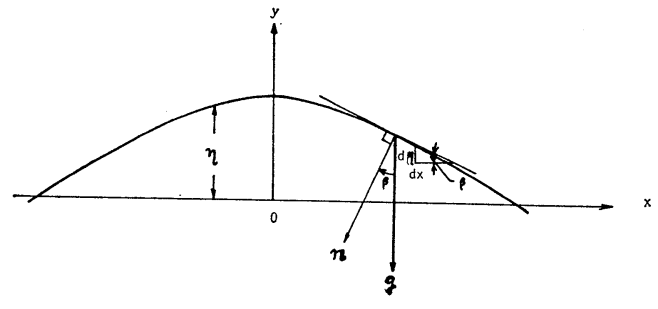

図一8 重力加速度の方向と内部境界面の変位方向との関係

図一8 を参照すると

$\sin \beta \simeq d_{\eta} / d x=-k H \sin k x$

式（8）に式（9）を代入すると

$$
\xi_{2}=-\left|g \cdot \frac{1}{\rho} \frac{\Delta \rho}{\Delta y}\right| k H \sin k x
$$

式 (6) と式 (10)により，攪乱波が加わったことにより， 内部境界面内に起る渦度の時間的変化率 $\xi$ は次式とな る.

$$
\xi=\xi_{1}+\xi_{2}=\left(\frac{1}{2} \alpha^{2} \Delta y k-\left|g \cdot \frac{1}{\rho} \frac{\Delta \rho}{\Delta y}\right|\right) k H \sin k x
$$

$\xi>0$ の場合には, 渦度は時間と共に増加し, それに伴い 内部境界面の変位が増幅し, 遂には破壊に至る. 一方, $\xi \leq 0$ の場合には界面は安定な状態に保たれることにな る.

\section{4.上・下両流体混合現象の周期性と連行量の 算定}

つぎに，上・下両流体間の混合現象が有する周期性に ついて考える. 水平な内部境界面に攪乱波が加わったこ とにより，内部境界面の任意の点において，界面内の渦 度に起因して生じる速度は, Scorer ${ }^{6)}$ が論じているよう に，次式により表わされる。

$$
u=\frac{1}{2} \alpha \cdot \Delta y k H \cos k x
$$

すなわち，変形した内部境界面内では，渦度は式（12） の速度で移動する。したがって，覺乱波の下りこう配部 では, 渦度は節に向って移動し, その節に拈ける渦度の 強さは時間と共に増加する。 また，この下りこう配部 では $\sin k x>0$ である.したがって式 (11)より， $\frac{1}{2} \alpha^{2} \Delta y k>g \Delta \rho / \rho \Delta y$ のときには，下りこう配部の節にお いては常に $\xi>0$ であり，内部境界面は下りこう配部節 において不安定となる，一方，覮乱波の上りこう配部で は式（12）により渦度は節から離れる方向に移動し，さ らに $\sin k x<0$ であるから $\frac{1}{2} \alpha^{2} \Delta y k>g \Delta \rho / \rho \Delta y$ のとき にはその部分の渦度は時間と共に弱まり，不安定とはな らない.

つぎに, $\frac{1}{2} \alpha^{2} \Delta y k<g \Delta \rho / \rho \Delta y$ の場合には，攪乱波の下 りこう配部の節では $\xi<0$ であり，内部境界面は安定を
保つ、また上りこう配部の節では，式（12）の関係によ り渦度は時間と共に弱まるので不安定化は起らない。

以上の結果, 厚さ $\Delta y$ の内部境界面の不安定化の条件 は次式により与えられる.

$$
\frac{1}{2} \alpha^{2} \Delta y k>\frac{g}{\rho} \frac{\Delta \rho}{\Delta y}
$$

内部境界面が变位して上式の条件を満すとき，攪乱波は 下りこう配節において不安定化して，上下流体間の混合 が起ることになる，すなわち，上層と下層の混合は内部 境界面ぞいに一様に生じるのではなくて, 攪乱波の波長 ごとに断続的に生じる.いま，不安定領域に属する攪乱 波の最大波長を $L_{c}$ とすると，式 (13) より

$$
L_{c}=\frac{2 \pi}{k_{c}}=\frac{\pi \alpha^{2} \Delta y}{\frac{g}{\rho} \frac{\Delta \rho}{\Delta y}}=\pi F_{r}^{2} h
$$

をうる.ここに， $h$ は上層水の厚さ，また $F r$ は次式で 定義される内部フルード数である.

$$
F_{r}=\frac{\Delta U}{\sqrt{g \frac{\Delta \rho}{\rho} h}}
$$

式（14）より次式をうる.

$$
\frac{L_{c}}{h}=\pi F_{r}^{2}
$$

著者らは, 上層を静止させ,一方, 厚さ $h_{2}$ の下層を 流動させた時の内部境界面の安定性につき実験を行い, 図一9に示す結果を得ている。図一11 の $F_{r l}^{2}$ は下層水 の厚さ $h_{2}$ を代表的長さに選えだ，次式により定義され るフルード数である.

$$
F_{r l}^{2}=\frac{\Delta U}{\sqrt{g \frac{\Delta \rho}{\rho} h_{2}}}
$$

この実験結果は，式（17）したがって式（16）の妥当性 迄示晙するものと考光られる。

また，内部境界面上の攪乱波の波長が式（16）で与え

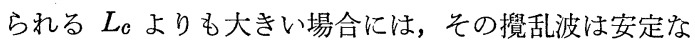
状態を保って伝播していく, 著者らは以前, 富山湾にお ける密度流フロントをLandsat により調査し, フロント 上の安定な大波長攪乱波の存在を提示したが7)，そのこ とは本論における式（16）で表わされる解析的推論と符 合するものと考えられる.

以上の考察によれば, 表層水の密度は攪乱波の波長ご とに断続的に平均密度を増していくが，この場合，上層 に混入した下層流体は直ちに上層全体の密度を均一化す るのではなく，現実には内部境界面ぞいに中間層を形成 する．この中間層厚さ $H$ (図一10参照) は Scorer $(1951)^{8)}$ によれば

$$
L \simeq 2.7 H
$$

である.したがって，表層水厚さ $h$ とフルード数 $F_{r}$ を 与えられた時の中間層厚さ $H_{c}$ は $F r$ によって決まるこ 


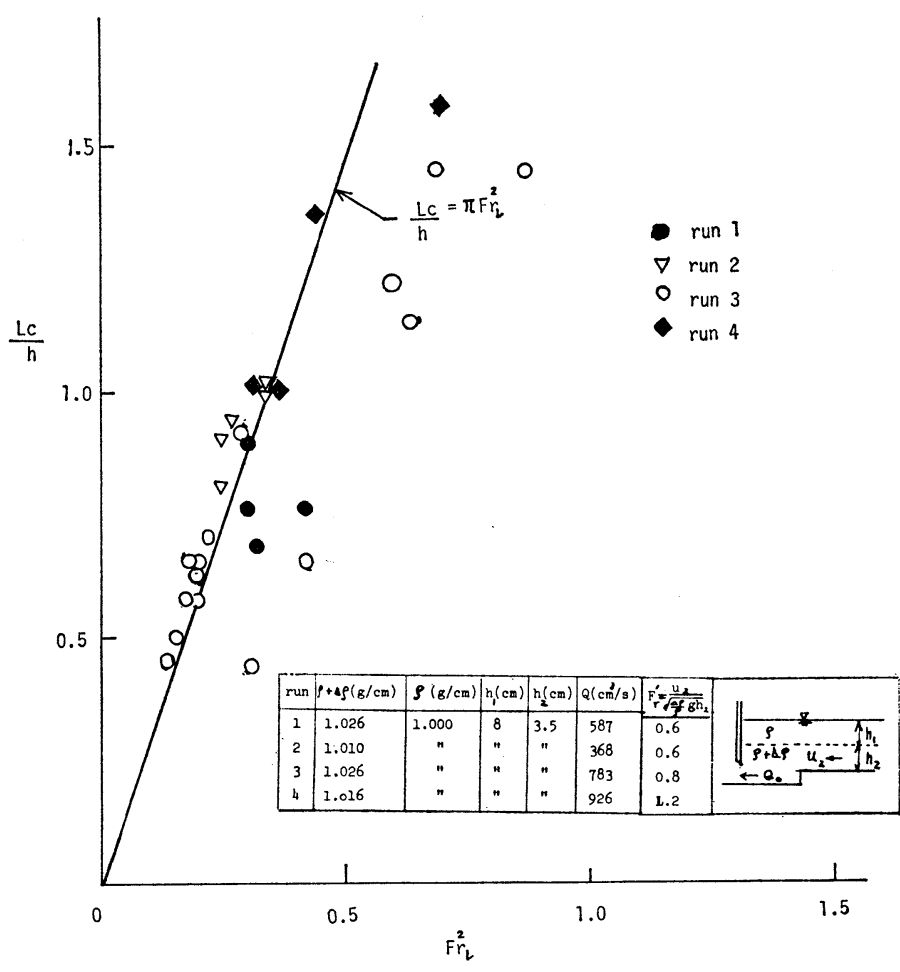

図一9 内部境界面上の攪乱波の不安定化限界

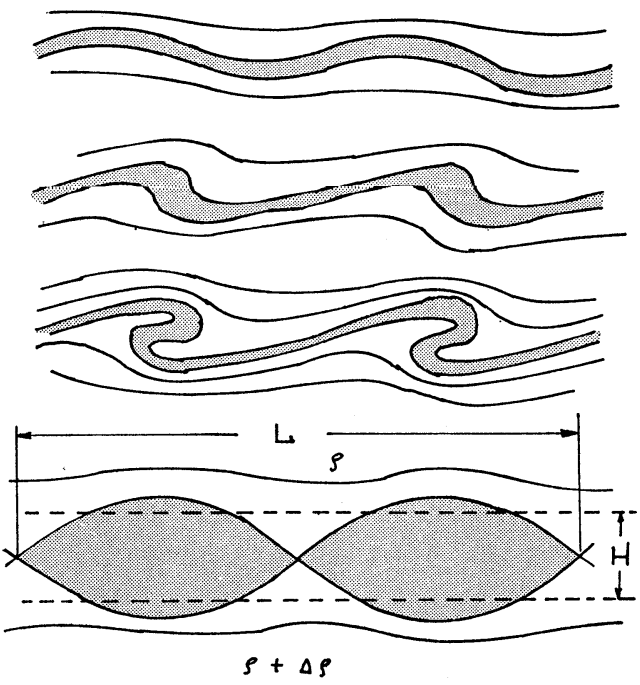

図-10 攪乱波による中間層の形成

とになる。すなわち，式（16）と式（18）より

$$
\frac{H_{c}}{h}=\frac{\pi}{2.7} F_{r}^{2}=1.16 F_{r}^{2} .
$$

をうる。攪乱波が加わる以前の内部境界面内の単位長さ 当りの流体平均質量は $(\rho+\Delta \rho / 2) \Delta y$ であり，それが攪乱 により混合されるととの平均質量は $(\rho+\Delta \rho / 2) H_{c}$ に変わ
ると考えると，その間の質量変化 $\Delta M$ は

$$
\begin{aligned}
\Delta M & =\left(H_{c}-\Delta y\right)\left(\rho+\frac{\Delta \rho}{2}\right) \\
& =\left(1.16 F_{r}^{2} h-\Delta y\right)\left(\rho+\frac{\Delta \rho}{2}\right)
\end{aligned}
$$

である、 $\Delta y, \Delta \rho$ が十分に小さい場合には

$$
\Delta M \simeq 1.16 \rho F_{r}^{2} h=1.16 \rho L_{c} / \pi
$$

となる. 式（20）は下層水の連行量はフ ルード数の二乗に比例することを示して おり，この事は“せん断流型の連行現象 では, 連行係数は局所的リチャードソ ン数に逆比例する”, ことに対応してい る.

\section{5. 結 語}

陸側から海域へ放出される排水の拡散 範囲の推算に際しては, 沖側の境界条件 として黑潮等の大規模な海流の分布をと り入れる必要のあることを, 実測例を用 いて提示した. また，洪水時の航空写真 に認められる 図一2 5 の上うな映像の 濃淡の原因を, 内部境界面の不安定性の面から捉えて考 察した. その結果, 海面へ放出される排水と海水との混 合は不連続な現象であることを示し，また，表層流への 下層水の連行量を表わす近似式として, 式（20）を提案 した.

\section{参考 文 献}

1) Scarpace, F. L., R. P. Madding and T. Green, III: Scanning thermal plumes, Proc. of 9th Inter. Symp. of Remote Sensing of Environment, pp. 939 961, 1974.

2）田中・杉村 · 大西・西村：沿岸の流動解析のための Landsat map の試作と流動の判読について, 第 35 回年土木学会年 講概要集, 第 2 部, p. 135, 1980.

3）大西外明 - 田中総太郎：Landsat による急傾斜湾内密度流 フロントの観測と安定性に関する考察, 土木学会論文報告 集, Vol. 292, pp. 53〜63, 1979.

4）関根義彦：黑潮流路に及ぼす伊豆海嶺の効果に関する圧順 モデル数值実験, 海洋科学 Symposium 2, 黑潮, pp. 166 171, 1978.

5) Scorer, R. S.: Environmental Aerodynamics, John Wiley \& Sons, p. 229, 1978.

6) Scorer, R. S.: 5) に同じ.

7）大西外明・田中総太郎：3）に同じ.

8) Scorer, R. S.: 5), p. 233.

9) 日野幹雄: 流体力学の進歩, 乱流 (谷一郎編), 丸善, p. 203, 1980. 